\title{
ANALISIS KEBIJAKAN PENGOPERASIAN TERMINAL GIWANGAN YOGYAKARTA SEBAGAI PENGGANTI TERMINAL UMBULHARJO
}

\author{
Meri Enita Puspita Sari S.IP.,MPA
}

\author{
( Dosen Program Studi Ilmu Pemerintahan, FISIPOL-UNRIKA)
}

\section{A. PENDAhUluan}

\section{Latar Belakang Masalah}

Transportasi merupakan salah satu sector yang sangat penting dan strategis dalam pembangunan. Dalam fungsinya sebagai Promoting sector dan servicing sector, tranportasi telah memegang peranan yang besar sebagai urat nadi perekonomian. Pembangunan sector transportasi dimaksudkan untuk menggerakkan berbagai potensi wilayah, meningkatan aksesbilitas dan mobilitas masyarakat, serta meningkatkan produktivitas kawasan perkotaan.

Sasaran utama pembangunan sector transportasi dibanyak wilayah adalah untuk mewujudkan adanya keseimbangan perkembangan sector-sektor ekonomi, terutama pada wilayah-wilayah dengan tingkat pertumbuhan tinggi, seperti Kota Yogyakarta yang tiap tahunnya teradi tingkat pertumbuhan jumalah penduduk yang tinggi. Peningkatan sarana dan prasarana transportasi bertujuan untuk menghubungkan sentra-sentra komersial dan fasilitas umum yang tersebar letaknya dengan sntra-sentra pemukiman penduduk, membuka kesempatan kerja, meningkatkan arus perhubungan antar kota kawasan hinterland-nya.

Pembangunan dan pengembangan kota Yogyakarta sekarang ini mulai diarahkan kekawasan Selatan Kota Yogyakarta, yang meliputi kecamatan Kotagede, Umbulharjo, dan Mantrijeron. Khususnya dikawasan kelurahan Giwangan Kecamatan Umbulharjo, sekarang dibangun Terminal Angkutan Penumpang Tipe A Giwangan untuk menunjang sarana transportasi dan sebagai pengganti terminal Penumpang Umbulharjo.

Ada beberapa factor yang melatar belakangi Kebijakan Pembangunan Terminal Tipe A Giwangan adalah :

1. Factor Teknis

a. Terminal Umbulharjo dengan luas $16.212 \mathrm{~m}^{2}$, dari segi kapasitas dan daya tamping sudah tidak memenuhi tuntutan kebutuhan bagi pelayanan transportasi bus AKAP, AKDP, Perkotaan/Kota dan Angkutan Pedesaan. Sebagai Terminal Tipe A satusatunnya di DIY selain terminal-terminal kecil lainnya, terminal umbulharjo tidak mungkin lagi dipergunakan karena kapasitasnya lebih kecil jika dibandingkan dengan jumlah bus yang masuk keterminal.

Tabel 1

Keadaan Terminal Bus di Kota Yogyakarta

\begin{tabular}{|l|l|l|c|c|c|}
\hline No & Kabupaten/kota & Nama Terminal & $\begin{array}{c}\text { Kapasitas } \\
\text { (Bus) }\end{array}$ & $\begin{array}{c}\text { Luas } \\
\text { Lahan } \\
\left(\mathrm{m}^{2}\right)\end{array}$ & Kondisi \\
\hline 1 & \multirow{2}{*}{ Yogyakarta } & Umbulharjo & 102 & 16.212 & Baik \\
\cline { 3 - 6 } & Rejowinangun & 30 & & Baik \\
\cline { 3 - 6 } & Terban & 50 & & Baik \\
\hline 2 & Sleman & Jombor & 30 & 400 & Baik \\
\hline
\end{tabular}




\begin{tabular}{|l|l|l|l|l|}
\hline & Condongcatur & & & Baik \\
\hline
\end{tabular}

Sumber : Dinas Perhubugan Propinsi DIY tahun 2000

Table 2

Rerata Pelayanan Bus di terminal Umbulharjo

\begin{tabular}{|cl|c|c|c|}
\hline & Jenis Angkutan Penumpang & Bus & RIT dating & RIT/jam \\
\hline 1. & Antar Kota Antar Propinsi (AKAP) & 836 & 1.138 & 47 \\
\hline 2. & Antar Kota salam Propinsi (AKDP) & 241 & 756 & 31 \\
\hline 3. Angkutan Perkotaan (APDP) & 258 & 1.714 & 142 \\
\hline \multicolumn{2}{|c|}{ Jumlah } & 220 \\
\hline
\end{tabular}

Sumber : Data Terminal Umbulharjo 1995/1996

Berdasarkan data diatas dapat disimpulkan bahwa terminal UmbulHarjo tidak mungkin lagi dapat menampung jumlah kendaraan yang tiap tahunnya mengalami peningkatan yang pada tahun 1995/1996 data menunjukkan angka 220 kendaraan untuk rerata pelayanan bus apalagi untuk jangka waktu 10 atau 20 tahun mendatang, sedangkan luas terminal hanya sebesar $16.212 \mathrm{~m}^{2}$ dengan kapasitas bus sebanyak 102 bus.

b. Pada lokasi di Terminal penumpang Umbulharjo tidak mungkin lagi dikembangkan karena terbatasnya lahan dan padatnya bangunan disekitar terminal.

c. Pemanfaatan jalan dalam kota oleh bus-bus besar (AKAP maupun AKDP) untuk sampai kelokasi terminal (Umbulharjo) secara teknik tidak diperbolehkan, karena luas jalan yang kecil namun kepadatan tinggi.

2. Factor Ekonomis

Pemilihan lokasi terminal di kawasan tumbuh kembang cepat (giwangan), sebagai langkah awal strategis Pemkot untuk menciptakan balance pertumbuhan antara wilayah Utara dan Selatan. Karena selama ini, wilayah perkembangan cenderung subur diyogya utara. Oleh karena itu, pembangunan terminal tidak hanya berisi fasilitas transfortas saja, namun juga prasarana lai sebagai gerbang aktivitas bisnis. Sehingga kawasan Kota Yogyakarta bagian selatan direncanakan perubahan landuse yang cukup medasar, yaitu adanya recana pasar induk Giwangan, pasar ikan, pasar buah, pasar burug dan fasilitas bongar muat barang, dimana peruahan tersebut akan terjadi perubahan pola penggerakkan orang dan barang dikawasan kota.

3. Faktor Sosial

Terminal umbulharjo dengan aktifitasnya yang padat setiap harinnya membuat ketidaknyamanan dalam masyarakat, ketidaknyamanan ini membuat pemerintah kota harus turun tangan dengan cara membuat kebijakan lainnya.

4. Faktor Ekologi

Kondisi lingkungan diteminal umbulharjo yang sudah terlalu padat akan mengakibatkan arus lintas yang tidak lancar, yang akhirnya akan meyebabkan terganggunya masyarakat sekitar dengan polusi udara dan suara serta gangguan lainnya.

Bila kita melihat dari segi lalu lintas dan transportasi, dibangunnya Terminal PenumpangTipe A Giwangan, sebagai pengganti terminal (lama) umbuharjo, akan berdampak kepada : 
a. Perubahan pola penggerakkan arus lalu lintas angkutan umum, baik Angkutan Umum, baik Angkutan Umum Antar Kota Antar Propinsi (AKAP), Antar Kota Dalam Propinsi (AKDP) maupun angkutan kota (bus kota).

b. Perubahan pola tata guna lahan ikawasan terminal, yang akan mempengaruhi pola perggerakkan arus lalu lintas dikawasan tersebut dan bangkitan parkir dibadan jalan.

c. Perubahan guna rung jalan akibat adanya bangkitan parkir dibadan jalan maupun adanya kegiatan informal di DAMIJA.

d. Adanya tarikan arus lalu lintas menuju keterminal karena adanya pusat bisnis di kawasan Inti Giwangan.

Namun adanya kendala keterbatasan keuangan pemkot Yogyakarta dalam pembangunan terminal penumpang tipe A tersebut, membuat pemerintah harus bekerjasama dengan pihak ketiga (sawasta), dan setelah diadakan pemilihan investor melalui tender, PT. Perwita karya kemudian terpilih untuk melakukan pembangunan secara fisik dengan system Build Operate and Transfer (BOT).

Dalam kerjasama tersebut Pemkot Yogyakarta menyertakan modal antara lain dalam bentuk penyertaan lahan calon lokasi terminal dan pembangunan beberapa bangunan infrastrutur seperti pagar terminal dan saluran air hujan (drainase), sedangakan investor betanggung jawab menyediakan semua biaya penyelesaian dan persyratan bangunnan terminal penumpang tipe A atau seluruh nilai bangunan utama dan pendukung lainnya serta bagunan infrastruktur yang diungsikan sebagai terminal, perbelanjaan, bangunan kantor dan fasilitas umum lainya.

Kebijakan pengoperasian terminal giwangan tersebut dalam pelaksaaannya harus berjalan dengan baik karena apabila tidak berjalan dengan baik maka akan terjadi penyimpangan atau adanya ketidakpuasan hasil yang dicapai dari kebijakan pembangunan terinal baru tersebut. Seperti yang dikeluhkan oleh berbagai masyarakat, diantaranya pedagang asongan yang dilarang berjualan didalam terminal, masyarakat sekitar yang tidak bisa mengais rezeki dan hanya bisa menonton ramainya terminal serta menerima polusi suara dan udara dari kendaraan yang lalu lalang, tidak adanya perubahan yang cukup mendasar dari terminal yang katanya jauh lebih luas dari terminal Umbulharjo karena masih terjadi antrian kendaraan, pemogokan supir-supir angkuatan pada saat setelah soft openingnya terminal tersebut dikarenakan perubahan jalur yang merugikan mereka, loket tiket yang letaknya jauh, kurang puasnya atau kekecewaan berbagai kalanga dari pelayanan atau hasil yang terjadi diterminal baru (giwangan) mulai dari awak bus, masyarakat pengunjung, masyarakat sekitar terminal, pihak-pihak yang terkait dengan pembangunan terminal tersebut (seperti pemkot dan Dishub), dan berbagai permaslahan lainnya, walaupun sekarang sudah agak berbenah menjadi lebih baik dari hari-hari awal soft opening terminal giwangan, baik yang dilakukan oleh pemerintah kota dengan dinas-dinas atau instansi terkaitnya maupun oleh PT. Perwita Karya.

\section{Transportasi Jalan}

Dikota Yogyakarta terdapat 16 jalur angkutan umum perkotaan dari 19 jalur ( 3 jalur yaitu jalur 8, 13 dan 18 tidak dioperasikan lagi karena jalur-jalur tersebut telah terjangkau oleh jalur-jalur yang lain ) yang menjangkau seluruh wilayah kota dengan asla dan tujuan terfokus pada terminal baru giwangan, sebagai pengganti terminal lama umbulharjo. Kecuali itu, dikota ini juga eroperasi jenis angkutan lain yang tidak terikat oleh jalur tertentu seperti taksi, andong, becak dan ojek. 
Jika dilihat dari armada yang sebesar 528 bus, 204 buah adiantarannya dikelola oleh KOPATA dengan sebagian besar kendaraan berumur diatas 15 tahun, 126 buah dikelola oleh KOBUTRI, masing-masing 111 buah bus dikelola oleh ASPADA dan PUSKOPAR, sisannya oleh Perum DAmri. Umur armada angkutan perkotaan di Kota Yogyakarta adalah diatas 15 tahun (64\% dari total armada), sisanya berkisar antara 5-15 tahun (36\% dari armada).

Selain dilayani dengan armada bus perkotaan, angkuatan umum lain yang tidak terikat oleh suatu trayek tertentu adalah taksi. Di Yogyakarta terdapat 748 armada taksi yang dikelola oleh 17 perusahaan taksi dengan rata-rata armada berumur dibawah 15 tahun. Untuk lebih jelasnya dibawah ini terdapat tabel jumlah armada angkutan perkotaan di Yogyakarta, yaitu :

Tabel 3

Jumlah Aramada Angkutan Perkotaan Di Kota Yogyakarta

\begin{tabular}{|c|c|c|c|c|c|c|c|}
\hline \multirow[t]{2}{*}{ No } & \multirow{2}{*}{$\begin{array}{l}\text { Perusahaan/ } \\
\text { Koperasi }\end{array}$} & \multicolumn{5}{|c|}{ Umur Kendaraan ( Tahun ) } & \multirow[t]{2}{*}{ Total kendaraan } \\
\hline & & $<5$ & $5-10$ & $10-15$ & $15-20$ & $20-25$ & \\
\hline 1 & Perum Damri & - & - & 15 & 15 & - & 30 \\
\hline 2 & KOPATA & - & 34 & - & 89 & 81 & 204 \\
\hline 3 & ASPADA & - & 2 & - & 36 & 73 & 111 \\
\hline 4 & PUSKOPKAR & - & 52 & 53 & 6 & - & 111 \\
\hline 5 & KOBUTRI & - & - & 54 & 72 & - & 111 \\
\hline & Jumlah & - & 88 & 122 & 218 & 154 & 582 \\
\hline & Prosentase & $0,00 \%$ & $15,12 \%$ & $20,96 \%$ & $37,46 \%$ & $26,46 \%$ & $100,00 \%$ \\
\hline
\end{tabular}

Sumber : Data Angkutan Perkotaan Dishub DIY 2001

\subsection{Kondisi terminal Umbulharjo yang menjadi latar belakang pengoperasian terminal Giwangan.}

Terminal lama umbulharjo menurut kategori klasifikasi dari Departemen Perhubungan No.a.596.AJ.010/1/7 tanggal 16 juli 1990, termasuk kategori Terminal Madya yaitu :

1. Melayani angkuata jarak jauh dengan volume sedang

2. Keluar/ amsuk bus $25 \mathrm{~s} / \mathrm{d} 50$ kendaraan per jam

3. Luas area tapak kegiatan terminal.

Sedangkan secara keseluruhan di terminal umbulharjo, bus antar kota yang masuk terminal sebanyak 1.313 buah bus, adapun rerata per jam bus masuk terminal anatara jam 06.00 WIB-17.00 WIB adalah 120 bus (untuk standar terminal kelas madya adalah 25 buah50 buah bus). Adapun rincian jam-jam sibuk bus keluar masuk terminal adalah sebaga berikut :

1. Jam 07.00 WIB $-08.00 \mathrm{WIB}=164$ bus/jam

2. Jam $11.00 \mathrm{WIB}-12.00 \mathrm{WIB}=162 \mathrm{bus} / \mathrm{jam}$

3. Jam 15.00 WIB $-16.00 \mathrm{WIB}=161 \mathrm{bus} / \mathrm{jam}$

Pada saat tertentu antara jam 07.30 WIB - 07.34 WIB memberangkatkan 11 buah bus jurusan trayek. Sehingga dimasa-masa mendatang tidak sesuai dengan kebutuhannya. Untuk lebih jelas dapat dikaji dengan melihat beberapa aspek kajian yang telah dilakukan seperti dibawah ini . Dari data transportasi Bus Antar Kota Antar Propinsi (AKAP), Bus Antar Kota Dalam Propinsi (AKDP), dan bus perkotaan di terminal Bus (Umbulharjo) baik bus datang/ berangkat dan jumlah penumpangnya adalah sebagai berikut : 
Tabel 4

Data Bus Antar Kota Antar Propinsi Untuk Bus Dan Penumpang Datang Dan Berangkat Di Terminal Bus Umbulharjo

\begin{tabular}{|l|c|c|c|c|c|}
\hline \multirow{3}{*}{ Bulan } & \multicolumn{5}{c|}{ Antar Kota Antar Propinsi } \\
\cline { 2 - 6 } & \multirow{2}{*}{ Bus } & \multicolumn{3}{|c|}{ Rit } & \multicolumn{2}{c|}{ Penumpang } \\
\cline { 2 - 6 } & & Datang & Berangkat & Datang & Berangkat \\
\hline Januari & 961 & 40.127 & 40.622 & 1.010 .693 & 1.040 .529 \\
\hline Februari & 1.155 & 42.220 & 41.147 & 1.412 .780 & 1.355 .918 \\
\hline Maret & 971 & 40.908 & 41.371 & 1.104 .031 & 1.131 .111 \\
\hline April & 973 & 40.139 & 40.371 & 1.004 .965 & 1.019 .875 \\
\hline Mei & 1.014 & 41.439 & 41.601 & 993.431 & 1.027 .814 \\
\hline Juni & 952 & 38.739 & 39.097 & 938.657 & 964.736 \\
\hline Juli & 936 & 39.370 & 39.786 & 924.101 & 969.544 \\
\hline Agustus & 950 & 39.169 & 39.489 & 850.701 & 878.609 \\
\hline September & 989 & 39.854 & 39.968 & 916.687 & 945.621 \\
\hline Oktober & 926 & 38.936 & 39.100 & 900.880 & 929.917 \\
\hline November & 984 & 38.936 & 39.547 & 940.393 & 980.529 \\
\hline Desember & 1.091 & 42.073 & 41.856 & 966.804 & 982.443 \\
\hline JUMLAH & 11.902 & 481.718 & 483.955 & 11.964 .323 & 12.226 .646 \\
\hline
\end{tabular}

Sumber : Rancang Bangun Terminal dan Penataan, 1996

Tabel 5

Data Bus Antar Kota Dalam Propinsi Untuk Bus dan Penumpang Datang Dan Berangkat Di Terminal Bus Umbulharjo

\begin{tabular}{|l|c|c|c|c|c|}
\hline \multirow{2}{*}{ Bulan } & \multicolumn{5}{|c|}{ Antar Kota Dalam Propinsi } \\
\cline { 2 - 6 } & \multirow{2}{*}{ Bus } & \multicolumn{2}{c|}{ Rit } & \multicolumn{2}{c|}{ Penumpang } \\
\cline { 2 - 6 } & & Datang & Berangkat & Datang & Penumpang \\
\hline Januari & 259 & 25.417 & 25.386 & 487.936 & 493.426 \\
\hline februari & 288 & 24.914 & 24.942 & 547.995 & 556.719 \\
\hline Maret & 271 & 26.131 & 26.017 & 580.261 & 551.195 \\
\hline April & 267 & 25.355 & 25.332 & 491.277 & 497.181 \\
\hline Mei & 270 & 26.099 & 26.081 & 512.294 & 524.702 \\
\hline Juni & 261 & 24.640 & 24.991 & 472.228 & 476.038 \\
\hline Juli & 271 & 25.810 & 25.921 & 446.561 & 463.937 \\
\hline Agustus & 272 & 25.629 & 25.709 & 415.129 & 427.583 \\
\hline September & 265 & 24.094 & 24.634 & 423.259 & 435.622 \\
\hline Oktober & 264 & 26.094 & 25.977 & 482.650 & 492.363 \\
\hline November & 276 & 26.381 & 26.362 & 472.246 & 488.891 \\
\hline Desember & 308 & 27.281 & 27.367 & 436.824 & 451.185 \\
\hline JUMLAH & 3.272 & 308.448 & 308.729 & 5.768 .660 & 5.858 .842 \\
\hline
\end{tabular}

Sumber : Rancang Bangun Terminal Dan Penataan, 1996

Tabel 6 
Data Bus Perkotaan Untuk Bus Dan Penumpang Datang Dan Berangkat Di Terminal Bus Umbulharjo

\begin{tabular}{|l|l|l|l|l|l|}
\hline \multirow{2}{*}{ Bulan } & \multicolumn{5}{|c|}{ Perkotaan } \\
\cline { 2 - 6 } & \multirow{2}{*}{ Bus } & \multicolumn{3}{c|}{ Rit } & \multicolumn{2}{c|}{ Penumpang } \\
\cline { 2 - 6 } & & Datang & Berangkat & Datang & Berangkat \\
\hline Januari & 326 & 55.034 & 55.146 & 641.551 & 655.042 \\
\hline februari & 325 & 51.710 & 51.787 & 666.675 & 695.050 \\
\hline Maret & 327 & 54.667 & 54.763 & 680.377 & 696.134 \\
\hline April & 329 & 53.753 & 53.827 & 650.086 & 663.445 \\
\hline Mei & 333 & 50.556 & 50.705 & 583.157 & 595.564 \\
\hline Juni & 345 & 51.486 & 51.487 & 611.226 & 624.315 \\
\hline Juli & 343 & 51.052 & 51.079 & 673.839 & 694.986 \\
\hline Agustus & 332 & 49.629 & 49.646 & 606.740 & 617.259 \\
\hline September & 352 & 47.595 & 47.511 & 579.557 & 586.787 \\
\hline Oktober & 354 & 53.011 & 53.067 & 668.029 & 669.360 \\
\hline November & 337 & 50.535 & 51.521 & 530.853 & 546.602 \\
\hline Desember & 374 & 58.563 & 58.568 & 713.973 & 724.930 \\
\hline JUMLAH & 4.077 & 627.591 & 628.107 & 7.606 .063 & 7.769 .374 \\
\hline
\end{tabular}

Sumber : Rancang Bangun Terminal Dan Penataan, 1996

Dengan melihat data-data tersebut diatas, untuk mengantisipasi perkembanga dimasa akan datanag dan kenyataanya frekuensi bus yang terjadi perlunnya dikembangkan menjadi terminal utama. Hal tersebut dapat dilihat dari prediksi frekuensi bus dari data-data tersebut diatas, yaitu sebagai berikut :

Tabel 7

Prediksi Transportasi Di Terminal Umbulharjo, Tahun 1997-2012

\begin{tabular}{|c|c|c|c|c|c|c|c|c|c|}
\hline Thn & \multicolumn{3}{|c|}{ Bus/Hari } & \multicolumn{3}{|c|}{ Penumpang Datang/Bulan } & \multicolumn{3}{|c|}{ Penumpang Berangkat/Bulan } \\
\cline { 2 - 10 } & AKAP & AKDP & APDP & AKAP & AKDP & APDP & AKAP & AKDP & APDP \\
\hline 1997 & 865 & 253 & 291 & 830.851 & 405.093 & 577.913 & 842.209 & 413.988 & 492.924 \\
\hline 1998 & 901 & 258 & 302 & 858.186 & 417.205 & 595.944 & 870.086 & 427.443 & 506.874 \\
\hline 1999 & 938 & 263 & 314 & 888.421 & 429.679 & 614.538 & 898.886 & 441.335 & 521.218 \\
\hline 2000 & 978 & 269 & 327 & 915.584 & 442.527 & 633.711 & 928.639 & 455.678 & 535.969 \\
\hline 2001 & 1019 & 274 & 340 & 945.707 & 455.758 & 653.483 & 959.377 & 470.488 & 551.136 \\
\hline 2002 & 1061 & 280 & 353 & 976.820 & 469.385 & 673.872 & 991.132 & 485.778 & 566.734 \\
\hline 2003 & 1106 & 285 & 387 & 1.008 .958 & 483.420 & 694.897 & 1.023 .939 & 501.566 & 582.772 \\
\hline 2004 & 1152 & 291 & 381 & 1.042 .152 & 497.874 & 716.577 & 1.057 .831 & 517.867 & 599.265 \\
\hline 2005 & 1200 & 297 & 396 & 1.076 .439 & 512.761 & 738.935 & 1.092 .845 & 534.698 & 616.224 \\
\hline
\end{tabular}




\begin{tabular}{|l|c|c|c|c|c|c|c|c|c|}
\hline 2006 & 1250 & 303 & 412 & 1.111 .854 & 528.092 & 761.989 & 1.129 .019 & 552.075 & 633.663 \\
\hline 2007 & 1302 & 309 & 428 & 1.148 .434 & 543.882 & 785.763 & 1.166 .389 & 570.018 & 651.598 \\
\hline 2008 & 1357 & 315 & 445 & 1.188 .218 & 580.144 & 810.279 & 1.204 .997 & 588.543 & 670.036 \\
\hline 2009 & 1413 & 322 & 462 & 1.225 .244 & 576.893 & 835.560 & 1.244 .882 & 607.671 & 688.988 \\
\hline 2010 & 1473 & 328 & 480 & 1.265 .555 & 594.142 & 861.629 & 1.282 .088 & 627.420 & 708.496 \\
\hline 2011 & 1534 & 335 & 499 & 1.307 .191 & 611.907 & 888.512 & 1.328 .657 & 647.812 & 728.547 \\
\hline 2012 & 1598 & 342 & 519 & 1.350 .198 & 630.203 & 926.234 & 1.372 .636 & 668.865 & 749.165 \\
\hline
\end{tabular}

Sumber : Studi ANDAL Lalu Lintas, FT.Sipil UGM, 1997

Dari tabel-tabel diatas dapat ditinjau hasil kajian dan rancang bangun terminal dengan kesimpulan sebagai berikut melalui Analisa Pergerakan :

a. Penumpang

Arus penumpang antar kota antar propinsi adalah penumpang yang datang lebih besar daripada yang berangkat, selisihnya 488.079 penumpang. Arus penumpang antar kota dalam propinsi adalah arus penumpang yang lebih kecil disbanding arus penumpang yang datang dan yang berangkat dari tahun 1990 sampai tahun 1995 ada kecenderungan naik.

b. Kendaraan

Bila dicermati angka pertumbuhan kendaraan kecenderungannya terus bertambah yang rata-rata pertumbuhannya sekitar $4 \%$. Jadi apabila direncanakan 20 tahun mendatang terminal akan melayani julah bus sebagai berikut :

Bus antar kota antar propinsi $=4.550 .892$

Bus antar kota dalam propinsi $=157.720$

Bus perkotaan dalam propinsi $=156.066$

\subsection{Deskripsi Terminal Giwangan}

Terminal giwangan merupakan terminal Tipe A dengan luas lahan sekitar 58.850 $\mathrm{m}^{2}$ dengan kapasitas (sesaat) sebagai berikut :

1. Kapasitas parkir untuk bus AKAP /AKDP $: 110$ buah.

2. Kapasitas parkir untuk taksi/umum/pengunjung : 165 buah.

3. Kapasitas parkir bus perkotaan $\quad: 60$ buah.

Dismaping itu parkir kendaraan juga dibangun jalur kedatanga/ pemberangkatan, sebagai berikut :

1. Jalur kedatangan bus AKAP/AKDP : 4 buah.

2. Jalur kedatangan bus perkotaan $: 4$ buah.

3. Jalur kedatangan bus AKAP/AKDP : 1 buah.

4. Jalur pemberangkatan bus AKAP/AKDP : 11 buah.

5. Jalur pemberangkatan bus perkotaan : 11 buah. 
Bila melihat data dari Analisis Dampak Lingkungan (ANDAL), pembangunan terminal Tipe A di dusn Mrican, Kelurahan Giwangan, Kecamatan Umbulharjo, Kota Yogyakarta, direncanakan terminal nantinnya dapat menampung dan melayani penumpang dan kendaraan sampai tahun 2014 (sumber studi kelayakan) adalah sebagai berikut :

1. Penumpang

2. Kendaraan bus antar kota

3. Bus Kota

4. Mobil Penumpang lain

5. Parkir Kedaraan Pribadi / taxi

6. Parkir Sepeda Motor
: 77.500 orang/hari.

: 248 bus/jam.

: $\quad 50$ bus/jam

: $186 \mathrm{buah} / \mathrm{jam}$.

: $130 \mathrm{mobil} / \mathrm{jam}$.

: 130 motor/jam

Terminal giwangan dengan analisis daya tampung, daya tampung area tunggu bus sesaat dapat diprediksi jumlah rit/jam pada 20 tahun mendatang adalah 428 bus/jam dengan jumlah parkir bus harus disediakan untuk sesaat 20 tahun mendatang adalah 112 pool dan kapasitas daya tampung bus kota adalah 274 bus dengan asumsi waktu tunggu bus 20 menit.

Dengan latar belakang diatas maka pengoperasian terminal giwangan sebagai pengganti terminal umbulharjo haruslah ditangani pengelolaannya oleh pihak yang tepat demi kelancaran dan kenyamanan kota melalui tata kota yang teratur.

\section{Rumusan Masalah}

Berdasarkan latar belakang masalah sehingga rumusan masalahnya adalah apakah pengoperasian terminal giwangan tersebut dapat membantu pemerintah dalam menyelesaikan permasalahan yang ada di terminal umbulharjo?

\section{Tujuan Kebijakan}

Tujuan dari analisis kebijakan pemerintah ini adalah untuk mengkaji kembali apakah formulasi kebijakan pengoperasian terminal giwangan dapat membantu pemerintah dalam menyelesaikan permasalahan kapasitas daya tampung terminal umbulharjo yang membuat kemacetan dan ketidaknyamanan masyarakat akibat kapasitas dan tata kota yang tidak sistematis atau teratur.

\section{Sasaran Kebijakan}

Untuk mencapai tujuan kebijakan maka sasaran kebijakan ini adalah penataan Tata Ruang Kota Yogyakarta agar dapat tertata dengan baik sehingga segala macam permasalahan yang menyangkut dengan tata ruang kota seperti keadaan lingkungan yang terlihat semrautan dan kumuh, kemacetan lalu lintas, polusi yang tiggi dan lain sebagainnya dapat diminimalisir sedemikian mungkin.

\section{B. PEMBAHASAN}

1. Alternatif Kebijakan

Berkaitan dengan Pengoperasian terminal Giwangan yang masih belum bisa membantu pemerintah dalam menyelesaikan permasalahan kepadatan jumlah angkutan umum dan kapasitas daya tampung terminal umbulharjo yang masih padat, maka diperlukan variable kebijakan yang dapat dijadikan pilihan bagi pemerintah dengan menggunakan aspek sebagi berikut :

1. Aspek Teknis 
Terminal penumpang Umbulharjo dari segi kaspistas dan daya tampung sudah tidak memenuhi tuntutan kebutuhan bagi pelayanan transportasi, keterbatasan lahan yang tidak bisa dikembangkan lagi dan pelanggaran terhadap pemanfaatan jalan raya.

2. Aspek Ekonomis

Langkah awal strategis Pemkot untuk menciptakan balance pertumbuhan antara wilayah utara dan selatan.

3. Aspek Sosial

Kondisi lingkungan di terminal umbulharjo yang sudah terlalu padat akan mengakibatkan arus lalu lintas tidak lancar, yang akhirnya akan menyebabkan terganggunnya masyarakat sekitar dengan polusi udara dan suara serta gangguan lainnya.

4. Aspek Ekologi

Lingkungan sekitar merupakan tetangga terdekat manusia, kenyamanan salah satunya tergantung dengan keadaan sekitar, apabila lingkungan sehat maka sumber daya manusiapun akan sehat pula, begitu juga dengan keadaan lingkungan sekitar terminal, padatnya terminal umbulharjo membuat polusi bagi masyarakat sekitar dimana hal itu menimbulkan ketidaknyamanan yang dirasakan oleh masyarakat terutama dimasalah kesehatan. Hal ini sangat perlu perhatian pemerintah khususnya pemerintah kota Yogyakarta.

Terdapat empat alternative kebijakan yang dapat dilakukan yaitu:

1. Status Quo.

Kebijakan ini dipilih untuk tetap melaksanakan kebijakan yang sudah ada yaitu pengoperasian terminal giwangan dalam meningkatkan pelayanan dengan memberikan ruang untuk angkutan umum dan penumpang yang kapasitasnya lebih besar. Kebijakan ini telah mampu memeratakan pembangunan dan mendongkrak perekonomian kawasan selatan dengan adanya pekerjaan baru pada masyarakat sekitar giwangan sebagai akibat berdirinya usaha-usaha baru karena lokasi giwangan yang telah ramai dari sebelumnya.

Selain itu, dengan berdirinya terminal yang lebih luas dan megah dari terminal lama telah memperlancar pengaturan lalu lintas kendaraan dalam terminal, menambah pendapatan pemerintah dari retribusi terminal di terminal dan menambah daya tarik yang lebih kepada pengunjung yang dating kekota Yogyakarta dengan adanya terminal yag bersih, nayaman dan megah.

2. Pengoperasian terminal Giwangan diserahkan oleh pihak swasta.

Dalam alternative kebijakan kedua ini, pengoperasian terminal giwangan dipegang oleh pihak swasta yaitu PT. Perwita Karya melalui pengesahan dengan dikeluarkannya SK Walikota Yogyakarta No. 212/ KD/ Tahun 2002, serta mendapat persetujuan dari Dewan melalui Keputusan Dewan Perwakilan Rakyat Daerah Kota Yogyakarta No. 37/K/DPRD/2002.

Adanya kendala keterbatasan keuangan pemerintah kota Yogyakarta dalam pembangunan terminal penumpang tipe A tersebut, ada baiknya apabila dalam pengoperasian dan pengelolaannya dikelolah oleh pihak swasta, mulai dari melakukan pembangunan secara fisik samapai dengan pengoperasian terminal setiap harinya.

Hal ini dilakukan agar permasalahan tata ruang kota yang tidak teratur, kapasitas angkutan yang sudah berlebihan, pelayanan yang kurang dan kemacetan yang semakin parah berkurang, sehingga masyarakat tidak perlu menunggu terlalu lama untuk 
mendapatkan semua kenyaman dalam menkmati pelayanan public yang seharusnya mereka terima.

3. Pengoperasian terminal Giwangan oleh pihak sawsta dan pemerintah.

Alternative ketiga ini dipilih untuk mendapatkan sebuah kerjasama yang baik antara pemerintah, pihak swasta dan masyarakat. Dalam alternative ini ditawarkan sebuah kerjasama pemerintah dan swasta dimana pemerintah menyertakan modal antara lain dalam bentuk penyerahan lahan lokasi terminal dan pembangunan beberapa bangunan infrastruktur seperti pagar terminal dan saluran air hujan (drainase).

Sedangkan investor bertanggungjawab menyediakan semua biaya penyelesaian dan persyaratan bangnan terminal penumpang tipe $\mathrm{A}$ atau seluruh nilai bangunan utama dan pendukung lainnya serta bangunan infrastuktur yang difungsikan sebagi terminal, perbelanjaan, bangunan kantor dan fasilitas umum lainnnya.

Dalam alternative ini dimaksudkan untuk mempermudah dan mempercepat pengoperasian terminal giwangan agar tidak menggunakan terminal umbulharjo lagi dan diketahui oleh masyarakat umum mengenai latar belakang kenapa terminal harus dipindahkan hingga terbentuknya kebijakan pengperasian terminal giwangan tersebut. Karena dengan diketahui masyarakat terhadap pembangunan terminal tersebut menjadi suatu hasil kebijkan yang benar-benar dapat dipertanggungjawabkan dan terhindar dari pandangan negative dikarenakan tidak adanya keterbukaan.

\section{Rekomendasi Kebijakan}

Rekomendasi kebijakan bertujuan untuk memberikan alternative kebijakan yang paling unggul disbanding dengan alternative kebijkan yang lain. Dalam proses pemilihan alternative tersebut harus mendasarkan pada seperangkat Kriteria yang jelas dan transparan, sehingga ada alasan yang masuk akal bahwa suatu alternative kebijakan dipilih atau ditolak. Rekomendasi membuahkan pengetahuan yang relevan dengan kebijakan tentang manfaat atau biaya dari berbagai alternative yang akibatnya dimasa mendatag telah diestimasikan melalui prakiraan.

Rekomendasi membantu mengestimasi tingkat resiko dan ketidakpastian, mengenali esternalitas dan akibat ganda, menentukan kriteria dalam pembuatan pilihan, dan menentukan pertanggungjawaban administrative bagi implementasi kebijakan. Dalam kebijakan pengoperasian terminal giwangan, rekomendasi kebijakan menggunakan metode perbandingan dengan cara membandingkan masing-masing alternative kebijakan . Diantara masing-masing kriteria dapat diberi bobot yang sama atau berbeda, semuanya tergantung pada asumsi yang digunakan. Alternative kebijakan yang mendapatkan jumlah nilai terbesar adalah yang layak dipilih secara rasional.

Dalam alternative kebijakan yang telah ada diatas akan dibandingkan dengan Kriteria kebijakan yang telah dijelaskan juga diatas lalu diberikan skor. alternative Skor tersebut yang dapat menentukan alternative kebijakan yang terbaik, secara otomatis kebijakan itu terpilih. Adapun penentuan variable kebijakan dari pengoperasian terminal giwangan sebagai pengganti terminal Umbulharjo dengan menggunakan tingkat manipulasi adalah sebagi berikut :

1. Rendah

2. Sedang

3. Tinggi

Tabel 8

Alternatif Kebijkan Pengoperasian Terminal Giwangan 


\begin{tabular}{|c|c|c|c|}
\hline \multirow[t]{2}{*}{ Kriteria } & \multicolumn{3}{|c|}{ Alternatif Kebijakan } \\
\hline & Status Quo & Pihak Swasta & Swasta dan Pemerintah \\
\hline $\begin{array}{l}\text { Aspek Teknis } \\
\text { a. Kapasitas dan } \\
\text { daya Tampung. } \\
\text { b. Luas Lokasi } \\
\text { c. Lalu Lintas }\end{array}$ & $\begin{array}{lr}\text { Kapasitas } & \text { yang } \\
\text { cukup } & \text { untuk } \\
\text { menampung } & \\
\text { angkutan, lokasi } \\
\text { yang luas dan lalu } \\
\text { lintas yang masih } \\
\text { kurang tertib. (2) }\end{array}$ & $\begin{array}{lr}\text { Kapasitas } & \text { yang } \\
\text { memadai, lokasi yang } \\
\text { strategis dan lalu } \\
\text { lintas yang masih } \\
\text { macet. }\end{array}$ & $\begin{array}{l}\text { Kapaistas dan daya } \\
\text { tampung yang terjamin, } \\
\text { lokasi strategis dan lalu } \\
\text { lintas yang tertib karena } \\
\text { diatur oleh pemerintah. } \\
\text { (3) }\end{array}$ \\
\hline 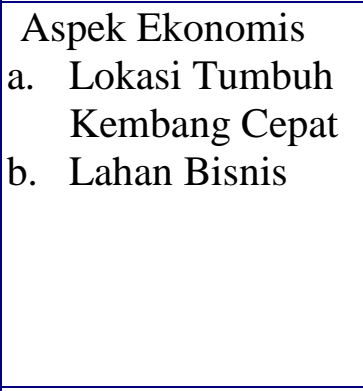 & $\begin{array}{l}\text { Lahan bisnis masih } \\
\text { dikuasai oleh } \\
\text { warga diluar } \\
\text { wilayah giwangan } \\
\text { sehingga bisnis } \\
\text { belum terlalu } \\
\text { menguntungkan (1) }\end{array}$ & $\begin{array}{l}\text { Swasta mendominasi } \\
\text { semua bidang } \\
\text { termasuk ekonomi, } \\
\text { bisnis berkembang } \\
\text { pesat namun tidak } \\
\text { terkontrol oleh } \\
\text { pemerintah. (2) }\end{array}$ & $\begin{array}{l}\text { Potensi wilayah } \\
\text { berkembang, } \\
\text { meningkatkan aksebilitas } \\
\text { dan mobilisasi } \\
\text { masyarakat, serta } \\
\text { meningkatkan } \\
\text { produktifitas } \\
\text { perkotaan.(3) }\end{array}$ \\
\hline $\begin{array}{c}\text { Aspek Sosial } \\
\text { Kenyamanan } \\
\text { Masyarakat }\end{array}$ & $\begin{array}{l}\text { Kenyamanan } \\
\text { masyarakat belum } \\
\text { terjamin }(1)\end{array}$ & $\begin{array}{l}\text { Masyarakat } \\
\text { mendapatkan } \\
\text { kenyamanan namun } \\
\text { pelayanan belum } \\
\text { optimal (2) }\end{array}$ & $\begin{array}{l}\text { Kenyamanan masyarakat } \\
\text { sudah terpenuhi, } \\
\text { pelayanan sudah } \\
\text { meningkat namun belum } \\
\text { terealisasikan dengan } \\
\text { baik. (2) }\end{array}$ \\
\hline $\begin{array}{l}\text { Aspek Ekologi } \\
\text { Kondisi Lingkungan } \\
\text { Sekitar Terminal }\end{array}$ & $\begin{array}{l}\text { Lingkungan penuh } \\
\text { polusi, sesak dan } \\
\text { padat angkutan. (1) }\end{array}$ & $\begin{array}{l}\text { Lingkungan berpolusi } \\
\text { namun tidak sesak dan } \\
\text { padat (2) }\end{array}$ & $\begin{array}{l}\text { Kemacetan dapat diatasi, } \\
\text { polusi berkurang dan } \\
\text { kepadatan menuru. (3) }\end{array}$ \\
\hline JUMLAH & 5 & 8 & 11 \\
\hline
\end{tabular}

Dalam tabel diatas terdapat kriteria kebijakan dari mulai aspek teknis berupa kapasitas dan daya tampung, luas lokasi dan lalu lintas, aspek ekonomis berupa lokasi tumbuh kembang cepat dan lahan bisnis, aspek social berupa kenyamanan masyarakat dan terakhir aspek ekologi berupa kondisi lingkungan sekitar terminal dan alternative kebijakan yang memiliki bobot tertinggi adalah alternative ketiga dengan tabel penentuan alternative kebijakan dibawah ini :

Tabel 9

Alternatif Kebijakan Terpilih

\begin{tabular}{|l|c|c|c|}
\hline \multicolumn{1}{|c|}{ Kriteria } & \multicolumn{3}{c|}{ Alternatif Kebijakan } \\
\cline { 2 - 4 } & Status Quo & Pihak Swasta & Swasta Dan Pemerintah \\
\hline $\begin{array}{l}\text { Aspek Teknis } \\
\text { a. Kapasitas dan daya Tampung. }\end{array}$ & 2 & 2 & 3 \\
b. Luas Lokasi Lalu Lintas & & & \\
\hline $\begin{array}{l}\text { Aspek Ekonomis } \\
\text { a. Lokasi Tumbuh Kembang Cepat } \\
\text { b. Lahan Bisnis }\end{array}$ & 1 & 2 & 3 \\
\hline
\end{tabular}




\begin{tabular}{|l|c|c|c|}
\hline $\begin{array}{l}\text { Aspek Sosial : } \\
\text { Kenyamanan Masyarakat }\end{array}$ & 1 & 2 & 2 \\
\hline $\begin{array}{l}\text { Aspek Ekologi : } \\
\text { Kondisi Lingkungan Sekitar Terminal }\end{array}$ & 1 & 2 & 3 \\
\hline \multicolumn{1}{|c|}{ JUMLAH } & 5 & 8 & 11 \\
\hline
\end{tabular}

Untuk skor atau bobot yang diberikan Stakeholders :
a. Rendah $=1$
b. Sedang $=2$
c. Tinggi $=3$

Dari tabel diatas, terlihat bahwa alternative ketiga memiliki skor tertinggi dibandingkan alternatif lainnya. Dalam pemberian skor, pengoperasian terminal giwangan sebagai pengganti terminal lama umbulharjo memiliki bobot yang besar yaitu 11 dimana semua aspek yang terdapat dala criteria yaitu aspek teknis, aspek ekonomis, aspek social dan aspek ekologi dapat membantu dalam menyelesaikan permasalahan yang ada sebelumnya diterminal umbulharjo. Karenanya alternative yang dipilih adalah alternative kebijakan yang ketiga dengan pengoperasian terminal giwangan diserahkan kepada pihak swasta dan pemerintah.

\section{Evaluasi Alternatif Kebijakan}

Dari alternative kebijakan terpilih, maka dapat di evaluasi hasil-hasil dari kriteria kebijakan tersebut untuk mengetahui kelebihan dan kelemahan masing-masing kriteria yang tersebut diatas, sehingga akan mendapatkan satu alternative kebijakan yang paling terbaik untuk di Implementasikan oleh pemerintah.

a. Alternatif 1 (Status Quo)

Dengan menggunakan kriteria-kriteria yang ada, dalam alternative 1, Pemerintah sudah berusaha untuk melaksanakan kebijakan demi kelangsungan hidup masyarakat baik dari aspek teknis, ekonomis, social maupun ekologi, namun dari semua aspek yang menjadi kriteria belum mampu mengatasi masalah yang ada di terminal umbulharjo sehingga diperlukan pengoperasian terminal giwangan yang mampu menampung kapasitas angkutan umum yang lebih banyak.

Dari segi teknis, alternative satu memiliki skor 2 berarti kebijakan tersebut sudah cukup mampu mengatasi masalah yang ada namun semakin lama, alternative ini tidak bisa lagi diperthankan seiring perkembangan zaman, jumlam transportasi meningkat dan dari social membuat ketidaknyamanan dalam masyarakat terutama segi ekologi karena mengganggu lingkungan.

Keunggulannya hanya ada dari segi ekonomis, itupun masih belum terlihat efektif karena hanya mendominasi dikalangan tertentu saja seperti tukang parkir. Belum seimbang dengan usaha-usaha yang lain sehingga keseimbangan pendapatan belum terpenuhi dan kesejahteraan masyarakat belum meningkat.

b. Alternatif 2 ( dioperasikan oleh pihak swasta)

Pihak swasta menduduki alternative terbaik ke 2, swasta cukup membantu pemerintah dari segi keuangan karena adanya kekurangan dana dari pemerintah. Swasta mampu memberikan dan menyediakan fasilitas-fasilitas yang dibutuhkan di terminal giwangan, hanya saja dalam alternative ini akan membuat pemerintah kesulitan dalam pengawasan terminal karena semua dilimpahkan oleh masyarakat, nantinnya kan berpengaruh terhadap ekonomi rakyat karena semua dipegang adan dikelola oleh pihak 
swasta. Sehingga dalam alternative ini belum bisa membantu pemerinatah dalam pengoperasian terminal giwangan jika berdiri sendiri.

c. Alternatif 3 (dioperasikan oleh pihak swasta dan pemerintah)

Dalam alternative ini ditawarkan kerjasama antara pemerinatah dan swasta, adanya kerjasama ini diharapkan mampu membantu pemerinatah dalam segala aspek yang menjadi criteria alternative kebijakan baik dari segi keuangan sampai dengan pelayanan public. Pihak swasta sebagai pengelola dan pemerintah sebagai pengawas pengoperasian terminal giwangan.

Dalam semua aspek, hanya alternative ini yang memiliki skor tertinggi karena memiliki sedikit kekurangan sehingga terpilih menjadi alternative kebijakan yang terbaik untuk direkomendasikan dibandingakan dengan criteria yang lainnya, walaupun masih memiliki kekurangan namun dengan seiringnya waktu diharapkan mampu mengurangi permasalahan yang ada.

\section{PENUTUP}

Implikasi atau dampak yang ditimbulkan dari kebijakan pengoperasian terminal tipe A giwangan ini yaitu terdapat dampak positif maupun negative, diantaranya adalah :

1. Dampak positif yang ditimbulkan

Dampak positif yang ditimbulkan dari kebijakan pengoperasian terminal giwangan, seperti tujuan awal dari kebijakan ini yaitu akan memeratakan pembangunan dan mendongkrak perekonomian kawasan selaan dengan adanya pekerjaan baru pada masyarakat sekitar giwangan sebagai akibat berdirinya usaha-usaha baru karena lokasi di gwangan telah ramai dari sebelumnya.

Selain itu, dengan berdirinya terminal yang lebih luas dan megah dari terminal lama akan memperlancar pengaturan lalu lintas kendaraan dalam terminal, menambah pendapatan pemerintah dari retribusi di terminal, dan menambah daya tarik yang lebih kepada para pengunjung yang datang ke kota Yogyakarta dengan adanya terminal yang bersih, nyaman dan megah ini.

Selain itu, kawasan ditengah kota tidak akan terganggu lagi dengan adanya bus AKAP dan AKDP yang lalu lalang menuju terminal lama umbulharjo yang terletak didalam kota karena keberadaan terminal yang baru ini terletak dipinggiran kota atau dekat dengan jalan Lingkar Selatan.

2. Dampak Negatif yang ditimbulkan

Dampak negative yang ditimbulkan dari pelaksanaan kebijakan ini adalah :

a. Persepsi masyarakat yang berupa rawannya tindak kejahatan, adanya vector penyakit yang muncul, adannya buangan limbah cair, penurunan kualitas udara dan rawannya kecelakaan.

b. Dari komponen kependudukan akan bertambahnya kepadatan penduduk dan mobilitas sehingga akan mengurangi kenyamanan sebagai kawasan tempat tinggal.

c. Terjadinya penindasan yang dilakukan oleh pihak investor kepada masyarakat yang menyewa kios-kios di dalam terminal sepert ketidakterbukaan pihak pengelola tentang masalah penyewaan kios dan biaya yang ditarik begitu besar. 
d. Akan timbulnya image jelek baru yaitu terminal baru giwangan sebagi mangkal PSK yang terkena gusur sebagai akibat dari kebijakan penanganan mereka yang kurang, apabila hal tersebut tidak ditanggulangi dari sekarang.

Buku :

\section{DAFTAR PUSTAKA}

Dunn, William N.2003, Pengantar Analisis Kebijakan Publik, Yogyakarta : Gadja Mada University Press.

Subarsono, AG,2008, Analisis Kebijakan Publik : Konsep Teori dan Aplikasinnya, Yogyakarta : Pustaka Pelajar.

\section{Sumber-sumber Lain :}

Akta No.02, Perjanjian Kerjasama antara Pemerintah Kota Yogyakarta dengan PT. Perwita Karya tentang Pembangunan dan pengelolaan terminal penmpang tipe A giwangan kota Yogyakarta, Kantor Tri agus Heryon SH. Notaries dan pejabat pembuat Akta Tanah di Sleman Taggal 9 september 2002.

Menyusun Masterplan Angkutan Umum Kawasan Tumbuh Cepat Kota Yogyakarta (Bahan Seminar). Pemerintah Kota Yogyakarta BAPPEDA dan Magister Sistem dan Teknik Transportasi Program Pasca Sarjana UGM, Tahun Anggaran 2003.

Studi Pola Jaringan Transportasi jalan Kota Yogyakarta (Laporan Pendahuluan), Pemerintah Kota Yogyakarta Dinas Perhubungan dan Pusat Studi Transportasi dan Logistik Universitas Gadjah Mada Yogyakarta, September 2003. 